\title{
PEMAHAMAN PENDIDIK SEKOLAH MENENGAH PERTAMA DALAM SISTEM PENILAIAN KURIKULUM 2013
}

\author{
Oleh: Ikhya Ulumudin*
}

\begin{abstract}
Government had implemented the 2013 Curriculum for 5 years now, however, in practice, there are still a lot of teachers who haven't fully comprehended this curriculum. Thus, it is intriguing to study "Junior High School Teacher's Comprehension on Assessment System in 2013 Curriculum". This study aims to find out the level of comprehension junior high school teachers have regarding the assessment technique in 2013 Curriculum. Furthermore, this study also tried to discern issues faced by teachers in implementing the assessment system in 2013 Curriculum. This study uses qualitative approach, and data were collected using questionnaires and focus group discussion (FGD). 5 sample locations were selected using purposive technique. The informants in FGD were 25 teachers and respondents filling the questionnaire were 4337 teachers. The result concludes that junior high school teachers' comprehension on the assessment system of 2013 Curriculum is still low and not optimal. There are also several issues in the implementation. Recommendation proposed are for a strategic and detailed dissemination and training, and also a simplification of the assessment system in 2013 Curriculum, especially in assessment for attitude aspect and descriptive assessment.
\end{abstract}

Keywords: attitude assessment, knowledge assessment, skill assessment.

\begin{abstract}
ABSTRAK
Pemerintah telah menerapkan Kurikulum 2013 selama 5 tahun, namun dalam pelaksanaannya banyak pendidik yang belum memahami sistem penilaiannya. Oleh karena itu, peneliti tertarik untuk mengkaji "Pemahaman pendidik Sekolah Menengah Pertama (SMP) dalam system penilaian kurikulum 2013". Tujuan penelitian ini adalah untuk mengetahui tingkat pemahaman pendidik sekolah menengah pertama mengenai teknik penilaian pada Kurikulum 2013. Selain itu, kajian ini juga menggali permasalahan yang dihadapi oleh pendidik dalam melaksanakan sistem penilaian pada Kurikulum 2013. Penelitian ini menggunakan pendekatan kualitatif dengan teknik pengumpulan data melalui pengisian kuesioner dan Diskusi Kelompok Terpumpun (DKT). Penentuan lima daerah sampel dilakukan dengan teknik purposif. Jumlah narasumber DKT sebanyak 25 pendidik dan jumlah responden kuesioner sebanyak 4.337 pendidik. Simpulan penelitian ini adalah tingkat pemahaman pendidik SMP dalam memahami sistem penilaian kurikulum 2013 masih belum optimal dan terdapat permasalahan dalam pelaksanaannya. Rekomendasinya adalah perlu dilakukan sosialisasi yang terencana dan menyeluruh serta penyederhanaan sistem penilaian pada kurikulum 2013 khususnya pada penilaian sikap dan penilaian pada bentuk deskripsi.
\end{abstract}

*Peneliti di Pusat Penelitian Kebijakan Pendidikan dan Kebudayaan Badan Penelitian dan Pengembangan Kementerian Pendidikan dan Kebudayaan Republik Indonesia 
Kata Kunci: Penilaian sikap, penilaian pengetahuan, dan penilaian keterampilan.

\section{PENDAHULUAN}

Penilaian merupakan serangkaian aktivitas untuk memperoleh informasi kualitatif dan kuantitatif baik ketika awal, sedang berlangsungnya proses, maupun di akhir pembelajaran yang bertujuan untuk mengevaluasi dan mendiagnosa kebutuhan yang harus diperbaiki sehingga pendidik dan peserta didik mampu meninjau, merencanakan, dan mengaplikasikan langkah-langkah yang harus ditempuh selanjutnya untuk mencapai tujuan pembelajaran (Purnomo, 2013). Penilaian hasil belajara pada jenjang pendidikan dan menengah diatur pada Peraturan Pemerintah Nomor 19 tahun 2005 tentang Standar Nasional Pendidikan. Dalam peraturan tersebut menyebutkan bahwa penilaian hasil belajar jenjang pendidikan dasar dan menengah terdiri atas penilaian hasil belajar oleh pendidik, penilaian hasil belajar oleh satuan pendidikan, dan penilaian hasil belajar oleh pemerintah.

Penilaian hasil belajar oleh pendidik bertujuan untuk memantau dan mengevaluasi proses, kemajuan belajar, dan perbaikan hasil belajar peserta didik secara berkesinabungan. Penilaian hasil belajar oleh pendidik dilakukan dalam bentuk ulangan, pengamatan, penugasan, dan/atau bentuk laian yang belaku. Penilaian hasil belajar oleh pendidik digunakan untuk mengukur dan mengetahui pencapain kompetensi peserta didik, memperbaiki proses pembelajaran, dan menyususn laparan kemajuan hasil belajar harian, tengah semester, akhir semester, akhir tahun, dan/atau kenaikan kelas (Peraturan Menteri Pendidikan dan Kebudayaan No. 23 tahun 2016 tentang Standar Penilaian) Penilaian hasil belajar oleh pendidik bertujuan untuk memantau dan mengevaluasi proses, kemajuan belajar, dan perbaikan hasil belajar peserta didik secara berkesinambungan. Penilaian hasil belajar oleh pendidik salah satunya dilakukan melalui penilaian harian. Penilaian harian adalah proses pengumpulan dan pengolahan informasi hasil belajar peserta didik yang digunakan untuk menetapkan program perbaikan atau pengayaan berdasarkan tingkat penguasaan kompetensi dan memperbaiki proses pembelajaran (assessment as dan for learning), dan mengetahui tingkat penguasaan kompetensi serta menetapkan ketuntasan 
penguasaan kompetensi (assessment of learning) (Dit. Pembinaan SMP, 2017).

Kemampuan guru dalam melakukan penilaian berhubungan dengan prestasi hasil belajar siswa. Hasil penelitian yang dilakukan oleh Fatmawati., Zainul,A., \& Mariatul, K. (2012) menyebutkan bahwa "Kemampuan penilaian guru yang baik berpengaruh terhadap ketuntasan belajar siswa". Namun kompetensi pemahaman guru dalam system penilaian masih belum optimal. Hal ini menyebabakan hasil belajar peserta didik tidak optimal apalagi dapat bersaing ditingkat internasional. Salah satu contoh benchmark internasional adalah PISA (Programme for International Students Assessment). PISA menguji literasi membaca, matematika, dan IPA pada siswa usia 15 tahun. 


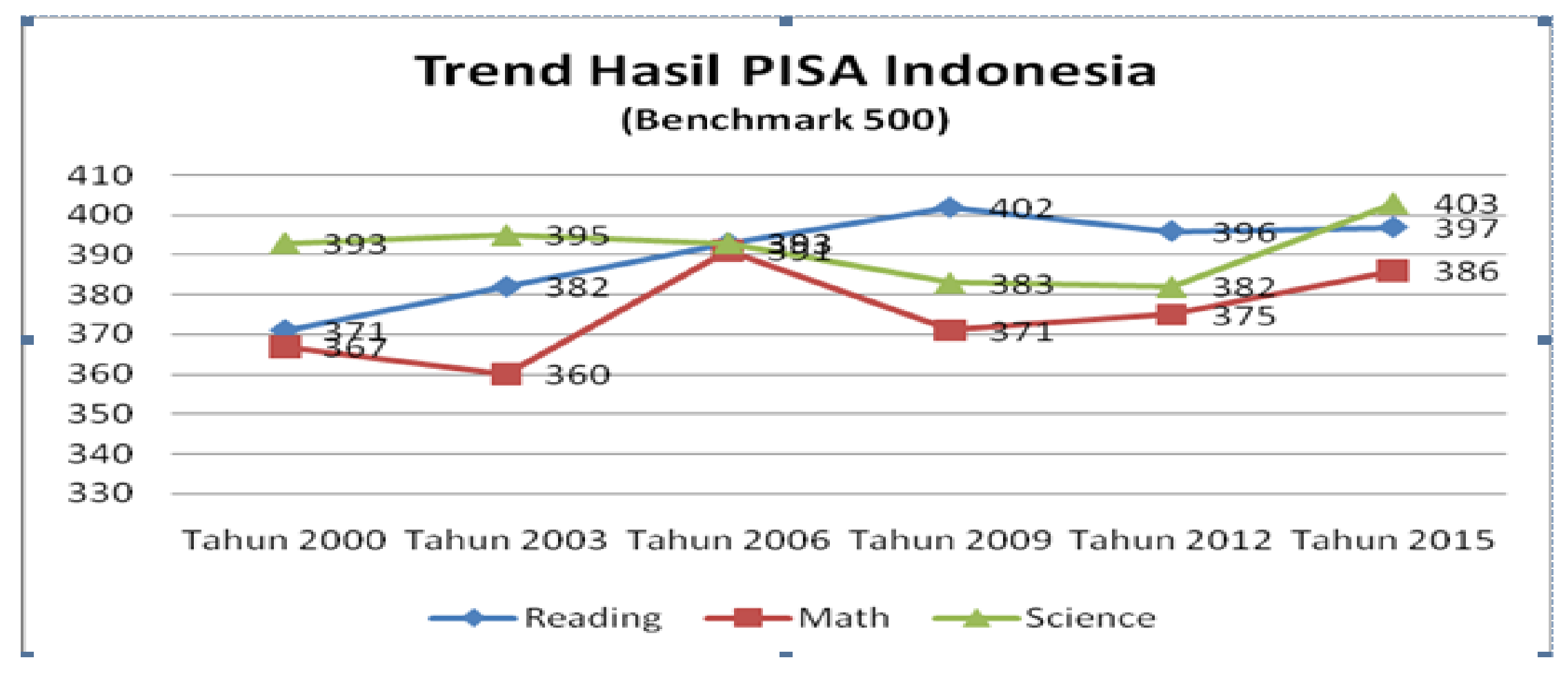

Sumber: OECD, 2015. 
Hasil PISA memperlihatkan peringkat Indonesia masih dibawah ratarata. Sejak Indonesia mengikuti program tersebut, skor dan posisi Indonesia relatif tetap di bawah rata-rata dan di peringkat bawah. Pada tahun nilai rata-rata reading sebesar 397, math sebesar 386, sedangkan science sebesar 403. Dari ketiga matapelajaran yang diujikan dibawah rata-rata internasional yakni 500 .

Rendahnya hasil belajar peserta didik salah satunya disebabkan kompetensi pendidik dalam melakukan penilaian belum memadai. Untuk itu pendidik dituntut dapat memahami system penilaian Kurikulum 2013. Dalam kaitannya dengan ini, peneliti tertarik mengkaji tentang "Pemahaman pendidik sekolah menengah pertama dalam system penilaian Kurikulum 2013". Penelitian ini bertujuan untuk mengetahui tingkat pemahaman pendidik sekolah menengah pertama mengenai teknik penilaian pada Kurikulum 2013 dan untuk mengetahui permasalahan yang dihadapi oleh pendidik dalam melaksanakan system penilaian pada Kurikulum 2013.

\section{KAJIAN TEORI}

Perbedaan makna antara penilaian, pengukuran, evaluasi memungkinkan terjadi dalam satu proses pembelajaran menyebabkan miskonsepsi bagi pendidik. Sebagian besar pendidik memandang tes adalah sama dengan melakukan penilaian untuk mengukur dan mengevaluasi kinerja peserta didik. Brookhart (2005) menjelaskan penilaian, pengukuran, dan evaluasi dengan contoh penerapan seperti berikut: Pendidik memberikan ujian tengah semester dan nilai peserta didik mencapai 64 persen, maka pendidik tersebut melakukan penilaian sekaligus pengukuran. Jika pendidik menggunakan informasi tersebut untuk menyimpulkan bahwa peserta-didiknya harus mendapatkan bantuan tambahan atau perbaikan tugas, maka pendidik melakukan evaluasi. Jika pendidik bertanya apa masalah yang mungkin terjadi, respon peserta didik merupakan informasi penilaian tetapi bukan pengukuran (tidak ada skala numerik). Penilaian pendidik tentang nilai wawasan peserta didik adalah evaluasi.

Sejalan dengan Brookhart, Purnomo (2014) mendefinisikan penilaian, pengukuran, dan evaluasi sebagai berikut. Penilaian merupakan 
serangkaian aktivitas untuk memperoleh informasi kualitatif dan kuantitatif baik ketika awal, sedang berlangsungnya proses, maupun di akhir pembelajaran untuk tujuan tertentu. Tes merupakan bagian dari tipe penilaian yang umumnya berisikan sekumpulan pertanyaan yang diberikan pada jangka waktu tertentu dalam kondisi seimbang untuk semua peserta didik. Pengukuran berarti menerapkan seperangkat aturan (beberapa skala skor) dari hasil tes atau tipe lain dari penilaian untuk mendapatkan informasi kuantitatif tentang hal tersebut (nilai atau angka dari beberapa jenis). Evaluasi berarti menggunakan informasi dari penilaian untuk membuat pertimbangan (keputusan) tentang nilai dari sesuatu.

Dalam sistem penilaian Kurikulum 2013 dijelaskan pada Peraturan Menteri Pendidikan dan Kebudayaan Republik Indonesia Nomor 23 tahun 2016 tentang Standar Penilaian, berikut adalah penjabarannya. Penilaian adalah proses pengumpulan dan pengolahan informasi untuk mengukur pencapaian hasil belajar peserta didik. Adapun ulangan adalah proses yang dilakukan untuk mengukur pencapaian Kompetensi Peserta Didik secara berkelanjutan dalam proses
Pembelajaran untuk memantau kemajuan dan perbaikan hasil belajar Peserta Didik.

Penilaian hasil belajar peserta didik pada pendidikan dasar dan pendidikan menengah meliputi aspek: a. sikap; b. pengetahuan; dan c. keterampilan. Penilaian sikap merupakan kegiatan yang dilakukan oleh pendidik untuk memperoleh informasi deskriptif mengenai perilaku peserta didik. Penilaian pengetahuan merupakan kegiatan yang dilakukan untuk mengukur penguasaan pengetahuan peserta didik. Penilaian keterampilan merupakan kegiatan yang dilakukan untuk mengukur kemampuan peserta didik menerapkan pengetahuan dalam melakukan tugas tertentu.

Penilaian hasil belajar oleh pendidik bertujuan untuk memantau dan mengevaluasi proses, kemajuan belajar, dan perbaikan hasil belajar peserta didik secara berkesinambungan. Penilaian hasil belajar oleh pendidik dilakukan dalam bentuk ulangan, pengamatan, penugasan, dan/atau bentuk lain yang diperlukan. Penilaian hasil belajar oleh pendidik digunakan untuk: (i) mengukur dan mengetahui pencapaian kompetensi Peserta Didik; (ii) memperbaiki proses pembelajaran; dan (iii) menyusun laporan kemajuan hasil belajar harian, tengah 
semester, akhir semester, akhir tahun. dan/atau kenaikan kelas.

$$
\text { Penilaian aspek sikap, }
$$

pengetahuan, dan keterampilan masingmasing terdiri atas beberapa tahap. Tahapan Penilaian aspek sikap dilakukan melalui: (i) mengamati perilaku peserta didik selama pembelajaran; (ii) mencatat perilaku peserta didik dengan menggunakan lembar observasi/pengamatan; menindaklanjuti hasil pengamatan; dan $\mathrm{d}$. mendeskripsikan perilaku peserta didik. Tahapan Penilaian aspek pengetahuan dilakukan melalui: (i) menyusun perencanaan penilaian; mengembangkan instrumen penilaian; (iii) melaksanakan penilaian; (iv) memanfaatkan hasil penilaian; dan (v) melaporkan hasil penilaian dalam bentuk angka dengan skala 0-100 dan deskripsi. Tahapan Penilaian aspek keterampilan dilakukan melalui: (i) menyusun perencanaan penilaian; mengembangkan instrumen penilaian; (iii) melaksanakan penilaian; (iv) memanfaatkan hasil penilaian; dan (v) melaporkan hasil penilaian dalam bentuk angka dengan skala 0-100 dan deskripsi.

\section{METODOLOGI PENELITIAN}

Penelitian ini menggunakan pendekatan kualitatif dengan teknik pengumpulan data melalui pengisian kuesioner dan Diskusi Kelompok Terpumpun (DKT). Pengisian kuesioner bertujuan untuk mengidentifikasi tingkat pemahaman pendidik SMP mengenai teknik penilaian pada Kurikulum 2013. Sedangkan DKT bertujuan untuk menggali informasi tentang permasalahan yang dihadapi pendidik dalam melaksanakan system penilaian kurikulum 2013. Pemilihan lokasi daerah sampel dilakukan dengan teknik purposive dengan kriteria mempunyai nilai Ujian Nasional (UN) tertinggi serta keterwakilan wilayah di Indonesia. Objek penelitian ini adalah pendidik jenjang Sekolah Menengah Pertama yang mengajar pada satuan pendidikan yang telah menerapkan Kurikulum 2013. Daerah sampel terpilih adalah Kota Banda Aceh, Kota Bekasi, Kabupaten Sleman, Kota Balikpapan, dan Kabupaten Manokwari. Penelitian dilakukan pada tanggal 8 Agustus - 14 September 2018.

DKT dilakukan di setiap kota/kabupaten sampel terpilih sehingga total pelaksanaan DKT adalah sebanyak lima kali. Narasumber DKT setiap daerah 
sampel terdiri dari pendidik satuan pendidikan satuan pendidikan SMP sebanyak 5 orang, sehingga total narasumber DKT adalah sebanyak 25 orang. Sementara itu, jumlah responden kuesioner dalam penelitian ini adalah sebanyak 4.337 pendidik yang terdiri dari Kota Banda Aceh sebanyak 415 pendidik, Kota Bekasi sebanyak 2.253 pendidik, Kabupaten Sleman sebanyak 496 pendidik, Kota Balikpapan sebanyak 1054 pendidik, dan Kabupaten Manokwari sebanyak 119 pendidik.

Pengolahan dan analisis data yang digunakan dalam penelitian ini adalah analisis deskriptif kuantitatif dan kualitatif. Analisis data kuantitatif digunakan untuk mengidentifikasi tingkat pemahaman pendidik SMP mengenai teknik penilaian pada Kurikulum 2013. Interpretasi data dilakukan dengan melihat jumlah pendidik yang telah memahami teknik penilaian Kurikulum 2013 melalui perhitungan persentase. Sedangkan analisis data kualitatif digunakan untuk menggali informasi permasalahan yang dihadapi pendidik dalam melaksanakan system penilaian kurikulum 2013. Interpretasi data dilakukan dengan mengidentifikasi permasalahan pendidik dalam melaksanakan system penilaian
Kurikulum 2013. Penarikan kesimpulan terhadap permasalahan-permasalahan tersebut dilakukan dengan melakukan triangulasi terhadap hasil kegiatan DKT yang dilakukan di lima daerah sampel.

\section{HASIL PENELITIAN DAN PEMBAHASAN}

Penilaian hasil belajar oleh pendidik bertujuan untuk memantau dan mengevaluasi proses, kemajuan belajar, dan perbaikan hasil belajar peserta didik secara berkesinambungan. Penilaian hasil belajar oleh pendidik salah satunya dilakukan melalui penilaian harian. Penilaian hasil belajar oleh pendidik meliputi tiga aspek penilaian, yakni penilaian aspek sikap, penilaian aspek pengetahuan, dan penilaian aspek keterampilan. Berikut ini dijabarkan pemahaman pendidik pada penilaian aspek sikap, aspek pengetahuan dan aspek keterampilan yang dilakukan oleh pendidik SMP.

\section{Penilaian Sikap}

Penilaian sikap merupakan kegiatan yang dilakukan untuk memperoleh informasi deskriptif mengenai perilaku peserta didik di dalam dan di luar pembelajaran. Penilaian kompetensi inti aspek sikap terdiri dari 
aspek sikap spiritual dan sosial. Teknik penilaian aspek sikap antara lain observasi, self-assessment, dan peerassessment. Pemahaman pendidik dalam menguasai teknik penilaian aspek sikap dalam Kurikulum 2013 sangat dibutuhkan agar dapat mengetahui dan memperbaiki sikap siswa secara tepat. Berikut ini adalah tabel persentase pemahaman pendidik terhadap teknik penilaian aspek sikap tersebut. 
Tabel. 4.1 Persentase Pemahaman Pendidik Terhadap Berbagai Teknik Penilaian Aspek Sikap

\begin{tabular}{|r|l|r|r|r|}
\hline \multicolumn{1}{|c|}{ No Daerah } & \multicolumn{2}{c|}{ Memahamni } & Memahami Sebagian & Tidak Memahami \\
\hline 1 & Kota Banda Aceh & 62.17 & 36.87 & 0.96 \\
\hline 2 & Kota Bekasi & 61.52 & 36.71 & 1.78 \\
\hline 3 & Kabupaten Sleman & 47.18 & 51.61 & 1.21 \\
\hline 4 & Kota Balikpapan & 54.55 & 43.45 & 1.99 \\
\hline 5 & Kab. Manokwari & 50.42 & 44.54 & 5.04 \\
\hline \multicolumn{2}{|c|}{ Total } & 57.94 & 40.28 & 1.78 \\
\hline
\end{tabular}


Pendidik yang memahami berbagai macam teknik penilaian aspek sikap sebesar $57,94 \%$ dan sisanya memahami sebagian dan tidak memahami (Tabel 4.1). Penilaian sikap merupakan hal yang baru pada Kurikulum 2013, mengingat pada kurikulum sebelumnya tidak secara eksplisit dalam menilai sikap peserta didik. Sehingga pendidik masih banyak yang kurang memahaminya, terutama pendidik yang sudah "senior".

Hasil penilaian sikap direkap oleh pendidik minimal dua kali dalam satu semester. Hasil penilaian sikap ini akan dibahas dan dilaporkan dalam bentuk deskripsi nilai sikap peserta didik. Berikut ini adalah tabel pemahaman pendidik terhadap pengelolahan dan pelaporan penilaian aspek sikap. 
Tabel 4.2. Persentase Pemahaman Pendidik Terhadap Pengolahan dan Pelaporan Penilaian Aspek Sikap

\begin{tabular}{|r|r|r|r|r|}
\hline \multicolumn{1}{|c|}{ No } & \multicolumn{2}{|c|}{ Memahamni } & Memahami Sebagian & Tidak Memahami \\
\hline 1 & Kota Banda Aceh & 65.54 & 0.72 & 0.96 \\
\hline 2 & Kota Bekasi & 49.18 & 2.62 & 1.78 \\
\hline 3 & Kabupaten Sleman & 45.97 & 1.41 & 1.21 \\
\hline 4 & Kota Balikpapan & 47.91 & 2.85 & 1.99 \\
\hline 5 & Kab. Manokwari & 48.74 & 4.20 & 5.04 \\
\hline \multicolumn{2}{|c|}{ Total } & 50.06 & 47.54 & 2.40 \\
\hline
\end{tabular}


Pemahaman pendidik dalam mengolah dan melaporkan penilaian aspek sikap bentuk predikat dan deskripsi masih belum maksimal, pendidik yang sudah memahami baru sekitar 50,06\%(Tabel 4.2). Pendidik yang belum memahami sebagian besar masih merasa bingung dalam menyimpulkan deskripsi hasil penilaian sikap peserta didik dari berbagai macam teknik penilaian. Selain itu wali kelas/guru kelas juga masih kesulitan dalam merumuskan nilai rapor dalam bentuk deskripsi sikap spiritual dan sosial setiap peserta didik karena bersumber dari beberapa pendidik.

Pada umumnya, penilaian aspek sikap oleh pendidik kepada peserta didik dilakukan melalui observasi kemudian dicatat pada lembar jurnal. Sikap peserta didik yang sangat baik dicatat pada lembar jurnal kemudian peserta didik diberikan reward misalnya berupa pujian. Sedangkan sikap peserta didik yang tidak baik dicatat pada lembar jurnal kemudian ditindaklanjuti dengan diberi bimbingan hingga sikap peserta didik tersebut menjadi baik. Perkembangan sikap peserta didik yang tidak baik dicatat pada lembar jurnal. Adapun teknik self assessment dan peer assessment dilakukan pendidik untuk mengonfirmasi hasil observasi.

\section{Penilaian Pengetahuan}

Penilaian pengetahuan merupakan kegiatan yang dilakukan untuk mengukur penguasaan pengetahuan peserta didik. Pengetahuan yang dinilai adalah pengetahuan yang tercantum dalam setiap mata pelajaran yang termuat pada KI-3 di setiap mata pelajaran. Teknik penilaian aspek pengetahuan terdiri dari tes tertulis, tes lisan dan penugasan. Agar dapat mengukur pengetahuan peserta didik secara tepat, pendidik dituntut untuk memahami penggunaan berbagai teknik penilaian aspek pengetahuan. 
Tabel. 4.3 Persentase Pendidik dalam Memahami Berbagai Macam Teknik Penilaian Aspek Pengetahuan.

\begin{tabular}{|r|r|r|r|r|}
\hline \multicolumn{1}{|c|}{ No Daerah } & \multicolumn{2}{c|}{ Memahamni } & Memahami Sebagian & Tidak Memahami \\
\hline 1 & Kota Banda Aceh & 70.60 & 28.67 & 0.72 \\
\hline 2 & Kota Bekasi & 68.89 & 29.69 & 1.42 \\
\hline 3 & Kabupaten Sleman & 59.48 & 39.72 & 0.81 \\
\hline 4 & Kota Balikpapan & 61.86 & 37.00 & 1.14 \\
\hline 5 & Kab. Manokwari & 57.14 & 41.18 & 1.68 \\
\hline Total & 65.94 & 32,83 & 1.22 \\
\hline
\end{tabular}


Pada Tabel 4.3 dapat dilihat bahwa masih terdapat pendidik yang memahami sebagian bahkan tidak memahami berbagai macam teknik penilaian pengetahuan. Pemahaman pendidik mengenai penggunaan berbagai macam teknik penilaian berdampak kepada pemahaman dalam menyusun indikator soal, membuat butir soal, dan membuat soal HOTS . Hal tersebut dapat dilihat dari pemahaman pendidik dalam menyusun indikator soal, membuat butir soal, dan membuat soal HOTS yang masih dibawah 50\%. Berdasarkan hasil kuesioner, pendidik yang memahami dalam menyusun indikator soal hanya sebesar 38,00\%. Pemahaman pendidik dalam membuat butir soal yang dijabarkan dari indikator soal sebesar 43,32\%. Demikian juga pemahaman pendidik dalam membuat butir soal bermuatan HOTS masih belum optimal, yaitu sebesar $33,00 \%$.

Penilaian aspek pengetahuan dilaksanakan dapat dilakukan satu kali untuk setiap KD, beberapa kali untuk KD yang cakupan materinya banyak, atau satu kali untuk beberapa KD yang cakupan materinya sedikit. Berikut ini adalah jumlah pelaksanaan penilaian harian yang dilakukan oleh pendidik SD dan SMP pada tiap semester.
Hasil penilaian pengetahuan diolah secara kuantitatif dengan menggunakan angka, predikat, dan deskripsi. Hasil penilaian pengetahuan dengan menggunakan angka ditulis dengan skala 1-100. Sementara itu, untuk predikat ditulis dengan huruf A (sangat baik), B (baik), C (cukup), dan D (kurang). Untuk deskripsi capaian pengetahuan didasarkan pada skor angka yang dicapai oleh KD tertentu. Berikut ini adalah tabel pemahaman pendidik dalam mengolah dan melaporkan penilaian aspek pengetahuan dalam bentuk angka, predikat, dan deskripsi. 
Tabel 4.4 Pemahaman Pendidik dalam Mengolah dan Melaporkan Penilaian Aspek Pengetahuan dalam Bentuk Angka, Predikat, dan Deskripsi

\begin{tabular}{|r|r|r|r|r|}
\hline \multicolumn{1}{|c|}{ No } & \multicolumn{1}{|c|}{ Merah } & \multicolumn{2}{c|}{ Memahami Sebagian } & \multicolumn{2}{c|}{ Tidak Memahami } \\
\hline 1 & Kota Banda Aceh & 70.36 & 29.64 & 0.00 \\
\hline 2 & Kota Bekasi & 55.30 & 42.61 & 2.09 \\
\hline 3 & Kabupaten Sleman & 52.62 & 45.36 & 2.02 \\
\hline 4 & Kota Balikpapan & 52.56 & 45.83 & 1.61 \\
\hline 5 & Kab. Manokwari & 52.10 & 43.70 & 4.20 \\
\hline Total & 55.68 & 42.49 & 1.82 \\
\hline
\end{tabular}


Pemahaman pendidik terhadap pengolahan maupun pelaporan penilaian aspek pengetahuan dalam bentuk angka, predikat, dan deskripsi masih belum optimal. yang memahami sebesar $55,68 \%$. Berdasarkan informasi yang disampaikan oleh pendidik, mereka beranggapan bahwa mengolah dan melaporkan nilai akhir adalah kegiatan yang rumit, dengan alasan keberagaman rentang nilai predikat pada mata pelajaran menyebabkan kebingungan walimurid karena dapat terjadi nilai angka yang sama menghasilkan nilai predikat yang berbeda. Hal tersebut karena penentuan rentang nilai predikat didasarkan pada nilai KKM masingmasing mata pelajaran. Selain itu pada pelaporan bentuk deskripsi, pendidik merasa kesulitan dalam menentukan KD yang akan digunakan sebagai deskripsi capaian pengetahuan peserta didik pada penilaian rapor. Selain itu, penulisan deskripsi memerlukan ketelitian dan waktu yang lama.

\section{Penilaian Keterampilan}

Penilaian keterampilan merupakan kegiatan yang dilakukan untuk mengukur kemampuan peserta didik dalam menerapkan pengetahuan dalam melakukan tugas tertentu. Penilaian keterampilan dapat dilakukan dengan berbagai teknik, antara lain penilaian praktik, produk, proyek, portofolio, dan teknik lain misalnya tes tertulis. Teknik penilaian keterampilan dipilih sesuai dengan karakteristik KD pada KI-4. Berikut ini adalah tabel yang menunjukan persentase pendidik tingkat SD dan SMP dalam memahami berbagai macam teknik penilaian pada aspek keterampilan. 
Tabel 4.5. Persentase pendidik dalam memahami berbagai macam teknik penilaian aspek keterampilan.

\begin{tabular}{|r|r|r|r|r|}
\hline No & \multicolumn{1}{|c|}{ Daerah } & Memahamni & Memahami Sebagian & Tidak Memahami \\
\hline 1 & Kota Banda Aceh & 65.30 & 34.46 & \\
\hline 2 & Kota Bekasi & 65.07 & 33.38 & \\
\hline 3 & Kabupaten Sleman & 53.83 & 45.36 & \\
\hline 4 & Kota Balikpapan & 58.06 & 4.24 \\
\hline 5 & Kab. Manokwari & 51.26 & 40.80 & 0.81 \\
\hline Total & 55.06 & 44.54 & 1.14 \\
\hline
\end{tabular}


Tingkat pemahaman pendidik mengenai berbagai macam teknik penilaian pada aspek keterampilan masih belum maksimal. Hal ini ditunjukan dengan persentase pendidik yang memahami sebesar $61,72 \%$. Kekurangpahaman pendidik terhadap berbagai teknik penilaian aspek keterampilan salah satunya disebabkan karena pendidik lebih sering melakukan penilaian hanya dengan menggunakan teknik tes tulis karena pada kurikulum sebelumnya, pendidik tidak dituntut untuk menilai aspek keterampilan di setiap mata pelajaran. Selain alasan tersebut, penggunaan berbagai teknik dalam penilaian aspek keterampilan memerlukan keahlian khusus dalam merancang proses penilaian di antaranya, penyusunan indikator dan kisi-kisi, penyusunan rubrik penilaian, penyusunan instrumen, dan pengolahan nilai.

Agar penilaian aspek keterampilan tidak dipengaruhi oleh subjektivitas penilai. untuk itu perlu dirumuskan pedoman/ rubrik penilaian sehingga dapat menyamakan persepsi penilai. 
Tabel 4.6 Persentase pendidik dalam memahami pembuatan rubrik penilaian

\begin{tabular}{|c|c|c|c|c|}
\hline No & Daerah & Memahamni & Memahami Sebagian & Tidak Memahami \\
\hline 1 & Kota Banda Aceh & 57.35 & 41.45 & 1.20 \\
\hline 2 & Kota Bekasi & 48.65 & 45.32 & 6.04 \\
\hline 3 & Kabupaten Sleman & 42.54 & 52.62 & 4.84 \\
\hline 4 & Kota Balikpapan & 52.56 & 43.83 & 3.61 \\
\hline 5 & Kab. Manokwari & 39.50 & 53.78 & 6.72 \\
\hline & Total & 49.48 & 45.65 & 4.87 \\
\hline
\end{tabular}


Pemahaman pendidik dalam membuat rubrik penilaian keterampilan masih rendah. Hal ini dapat dilihat pada tabel 4.6 yang memperlihatkan pendidik hanya 49,48\%. Hal ini Dikarenakan pendidik belum terbiasa menyusun rubrik penilaian keterampilan. Selain itu keterampilan menggunakan computer dan menghitung pendidik masih terdapat beberapa yang belum menguasai. Padahal ketrampilan menggunakan computer dan berhitung merupakan hal yang wajib dikuasi untuk membantu mempermudah pengolahannya.

Penilaian keterampilan dapat disajikan dalam bentuk nilai rata-rata dan/atau nilai optimum, sedangkan nilai akhir penilaian keterampilan dihitung dari rerata nilai seluruh KD. Nilai optimum diberlakukan apabila penilaian dilakukan terhadap KD pada materi dan teknik penilaian yang sama dan penilaian dilakukan lebih dari satu kali. Berikut adalah pemahaman pendidik dalam pengolahan penilaian aspek keterampilan. 
Tabel 4.7 Pemahaman pendidik dalam mengolah dan melaporkan penilaian aspek keterampilan dalam bentuk angka, predikat, dan deskripsi.

\begin{tabular}{|c|c|c|c|c|}
\hline No & Daerah & Memahamni & Memahami Sebagian & Tidak Memahami \\
\hline 1 & Kota Banda Aceh & 68.43 & 31.57 & 0.00 \\
\hline 2 & Kota Bekasi & 54.19 & 43.54 & 2.26 \\
\hline 3 & Kabupaten Sleman & 50.40 & 46.77 & 2.82 \\
\hline 4 & Kota Balikpapan & 50.38 & 47.82 & 1.80 \\
\hline 5 & Kab. Manokwari & 49.58 & 47.90 & 2.52 \\
\hline \multicolumn{2}{|r|}{ Total } & 54.07 & 43.92 & 2.01 \\
\hline
\end{tabular}


Dalam mengolah dan melaporkan penilaian aspek keterampilan dalam bentuk nilai, predikat, dan deskripsi. Pendidik yang memahami sebesar $54,07 \%$. Salah satu yang membuat guru kurang memahaminya adalah cara penentuan hasil penilaian akhir pada aspek keterampilan. Hasil Penilaian Akhir (HPA) merupakan hasil pengolahan dari HPH, HPTS, dan HPAS dengan menggunakan formulasi dengan atau tanpa pembobotan yang ditetapkan oleh satuan pendidikan.

Berdasarkan data nilai PH, PTS, dan PAS/PAT, satuan pendidikan dapat melakukan pembobotan menentukan nilai rapor. Misalnya, pengolahan nilai rapor disepakati oleh satuan pendidikan bahwa bobot untuk NPH $=50 \%$, NPTS $=$ $25 \%$, dan NPAS/NPAT $=25 \%$, maka penghitungan nilai rapor sebagai berikut. $\mathrm{HPA}=(2 \mathrm{x}$ HPH $)+(1 \times \mathrm{xPTS})+$ (1+HPAS)/4. Rumus ini digunakan mayoritas satuan pendidikan baik SD maupun SMP. Pendidik SD yang menggunakan pembobotan HPA seperti ini sebanyak 96,65\% sedangkan tingkat SMP sebanyak 93,76.

Dari hasil DKT disebutkan bahwa alasan pendidik belum sepenuhnya memahami dan menerapkan penilaian aspek sikap, pengetahun, dan keterampilan pada Kurikulum 2013 antara laian: (i) belum semua pendidik mendapatkan pelatihan tentang Kurikulum 2013; (ii) pendidik merasa kesulitan dalam memahami panduan pendilaian; (iii) pendidik merasa kesulitan dan memerlukan waktu yang lama dalam menerapkan system penilaian pada Kurikulum 2013; dan (iv) Pendidik merasa kesulitan dalan melakukan penilaian akhir nilai rapor dalam bentuk deskripsi pada aspek sikap, pengetahuan, dan keterampilan kurang.

\section{SIMPULAN DAN SARAN}

\section{Simpulan}

Kemampuan pendidik dalam memahami sistem penilaian kurikulum 2013 masih belum optimal. Hal ini dapat dilihat karena masih sekitar $60 \%$ pendidik yang telaha memahami sistem penilaian yang dilihat dari penilaian sikap pengetahuan dan keterampilan. Pada aspek sikap, pendidik yang memahami berbagai macam teknik penilaian aspek sikap hanya sebesar 57,94\%, Sedangkan pemahaman pendidik dalam mengolah dan melaporkan penilaian aspek sikap bentuk predikat dan deskripsi masih belum maksimal, pendidik yang sudah memahami baru sekitar 50,06\%. Pada aspek pengetahuan, pendidik yang 
memahami berbagai macam teknik penilaian aspek pengetahuan sebesar 65,94\%. Sementara itu pemahaman pendidik terhadap pengolahan maupun pelaporan penilaian aspek pengetahuan dalam bentuk angka, predikat, dan deskripsi yang memahami sebesar $55,68 \%$. Pada aspek pengetahuan, tingkat pemahaman pendidik mengenai berbagai macam teknik penilaian pada aspek keterampilan yang memahami sebesar $61,72 \%$ dan memahami dalam membuat rubrik penilaian keterampilan hanya 49,48\%. Sementara itu, dalam mengolah dan melaporkan penilaian aspek keterampilan dalam bentuk nilai, predikat, dan deskripsi pendidik yang memahami sebesar 54,07\%.

\section{Saran}

Alasan pendidik belum sepenuhnya memahami dan menerapkan penilaian aspek sikap, pengetahun, dan keterampilan pada Kurikulum 2013 antara laian: (i) belum semua pendidik mendapatkan pelatihan tentang Kurikulum 2013; (ii) pendidik merasa kesulitan dalam memahami panduan pendilaian; (iii) pendidik merasa kesulitan dan memerlukan waktu yang lama dalam menerapkan system penilaian pada Kurikulum 2013; dan (iv) Pendidik merasa kesulitan dalan melakukan penilaian akhir nilai rapor dalam bentuk deskripsi pada aspek sikap, pengetahuan, dan keterampilan kurang. Untuk itu perlu dilakukan: (i) sosialisasi yang terencana tentang penerapan Kurikulum 2013 khususnya pada sistem penilaian; (ii) Pemberian contoh penerapan dalam melakukan penilaian pada panduan penilaian; (iii) penyederhanaan system penilian pada kurikulum 2013 khususnya terkait penilaian sikap, penilaian keterampilan, dan pemberian deskripsi pada penilaian pengetahuan dan keterampilan; (iv) Pemberian deskripsi pada aspek sikap di kelola oleh walikelas, sedangkan pengetahuan dan keterampilan pemberian deskripsi dimunculkan seluruh KD.

\section{DAFTAR PUSTAKA}

Brookhart, S. M. 2005. Assessment Theory for College Classrooms. New Directions for Teaching and Learning, 100(Winter, 2004): 5-14.

Direktorat Pembinaan SMP. 2017. Panduan Penilaian oleh Pendidik dan Satuan Pendidikan Sekolah Menengah Pertama. Jakarta: Kementerian Pendidikan dan Kebudayaan.

Fatmawati., Zainul,A., \& Mariatul, K. (2012) "Kemampuan Guru 
Melakukan Penilaian Dalam Pembelajaran Pendidikan Kewarganegaraan (PKn) Di Sma Negeri 1 Banjarmasin. Jurnal Pendidikan Edisi Ke-2, No. 4, Nopember 2012.

OECD, 2015. PISA 2015 Results: Excellence and Equity in Education Volume 1, diakses dari www.oecd.org/pisa/ pada 20 April 2017.

Peraturan Menteri Pendidikan dan Kebudayaan Republik Indonesia Nomor 23 tahun 2016 tentang Standar Penilaian. Jakarta: Kementerian Pendidikan dan Kebudayaan.

Peraturan Pemerintah Republik Indonesia Nomor 19 tahun 2005 tentang Standar Nasional Pendidikan.

Purnomo, Y. W. 2013. Keefektifan Penilaian Formatif terhadap Hasil Belajar Matematika Mahasiswa Ditinjau dari Motivasi belajar. Makalah dipresentasikan dalam Seminar Nasional Matematika dan Pendidikan Matematika dengan tema "Penguatan Peran Matematika dan Pendidikan Matematika untuk Indonesia yang Lebih Baik" pada tanggal 9 November 2013 di Jurusan Pendidikan Matematika FMIPA UNY.

Purnomo. 2014. Assessment Based Learning: Sebuah tinjauan untuk meningkatkan motivasi belajar dan pemahaman matematis. Jakarta: Universitas Prof. Dr Hamka. 